\title{
PENERAPAN METODE JURNAL REFLEKTIF BERBASIS HIGH ORDER THINKING SKILL (HOTS) DALAM MENULIS MAKALAH
}

\author{
Diena San Fauziya ${ }^{1}$, Yusep Ahmadi ${ }^{2}$, Aurelia Sakti Yani ${ }^{3}$ \\ Pendidikan Bahasa dan Sastra Indonesia, Fakultas Pendidikan Bahasa, IKIP Siliwangi \\ Surel:dienasanf@gmail.com ${ }^{1}$ \\ yyusepp@yahoo.com ${ }^{2}$ \\ aurelia@ikipsiliwangi.ac.id ${ }^{3}$
}

\begin{abstract}
Abstrak
Penelitian ini bertujuan untuk menguji keefektifan metode penulisan jurnal reflektif berbasis High Order Thinking Skills (HOTS) dalam pembelajaran menulis makalah melalui pengujian perbedaan menulis makalah sebelum dan setelah perlakuan. Metode penelitian yang digunakan adalah eksperimen. Penelitian ini dilakukan pada 34 mahasiswa Program Studi Pendidikan Bahasa dan Sastra Indonesia IKIP Siliwangi. Teknik pengumpulan data melalui portofolio hasil menulis makalah mahasiswa sebelum dan setelah perlakuan. Hasil yang diperoleh adalah 1) tidak terdapat perbedaan antara kemampuan menulis makalah sebelum dan setelah penulisan jurnal reflektif dengan hasil perhitungan nilai signifikansi 0,128>0,05. Hal ini menunjukkan bahwa kesadaran mahasiswa tidak cukup berpengaruh terhadap perbaikan dalam menulis makalah. 2) Nilai menulis makalah mahasiswa masih berada pada rata-rata nilai 40. Ini menunjukkan bahwa kemampuan menulis mahasiswa masih jauh di bawah nilai ideal yang diharapkan, yakni minimal 80 . Rekomendasi untuk pembelajaran dan penelitian selanjutnya adalah diperlukan upaya konkret dan praktis untuk meningkatkan kemampuan mahasiswa dalam menulis makalah.

Pendidikan Bahasa, Sastrar

Indonesia dan Doverah
\end{abstract}

Kata Kunci: jurnal reflektif, High Order Thinking Skill, makalah, dan karya ilmiah.

\section{Abstract}

This study aims to test the effectiveness of reflective journal writing methods based on High Order Thinking Skills (HOTS) in learning to write papers through testing differences in writing papers before and after treatment. The research method used 
is experiment. This research was conducted on 34 students of the Indonesian Language and Literature Education Study Program IKIP Siliwangi. Data collection techniques through the portfolio of the results of writing student papers before and after treatment. The results obtained are 1) there is no difference between the ability to write papers before and after writing reflective journals with the results of the calculation of the significance value of 0.128>0.05. This shows that student awareness is not enough to influence the improvement in writing papers. 2) The value of writing student papers is still at an average value of 40. This shows that the student's writing ability is still far below the expected ideal value, which is at least 80. Recommendations for learning and further research is that concrete and practical efforts are needed to improve students' abilities in writing a paper.

Keywords: reflective journal, High Order Thinking Skill, papers, and scientific work.

\section{PENDAHULUAN}

Bagi seorang mahasiswa, kemampuan menulis makalah merupakan salah satu kecakapan yang harus dimiliki secara mumpuni. Bagaimana tidak, hampir setiap mata kuliah membebani mereka dengan tugas menulis makalah. Adanya Surat Dirjen Dikti No. 152/E/T/2012 mengenai wajib publikasi ilmiah bagi mahasiswa juga menjadi regulasi yang penting diperhatikan mahasiswa.

Permasalahan yang muncul adalal llmiah bahwa salah satu hambatan penyeah makalah yang disusun mahasiswa belum sesuai dengan indikator yang seharusnya dan cenderung hanya berupa salinan teori pun terkadang dengan referensi yang tidak jelas. Setelah ditelusuri, salah satu faktornya adalah teknologi yang memudahkan seringkali disalahgunakan sehingga mahasiswa cenderung mencari yang "instan”, yakni menyalin dan memindahkan tulisan ke dalam makalah tanpa mengacuhkan aturan pengutipan.

Hasil penelitian Cahyani (2010: 176) pun menunjukkan bahwa mahasiswa cenderung sulit menyusun makalah. Kendalanya adalah mahasiswa cenderung tidak melakukan perbandingan antara teori dengan yang terjadi di lapangan sehingga daya kritis rendah. Selain itu, Yuwono (2009: 74) mengemukakan adalah faktor pengembangan gagasan. Kondisi semacam ini dipandang oleh Warsono (2016: 271) bahwa minimnya kemampuan dan ketajaman analisis di kalangan pelajar dan mahasiswa lebih disebabkan oleh proses pembelajaran yang tidak mengedepankan aspek penalaran. 
Proses menulis makalah yang sering terjadi dilakukan dengan metode resitasi atau penugasan. Dari cara itu, seringkali ada proses yang tidak dinilai dan luput dari pembimbingan. Dengan berdasar pada paradigma baru pembelajaran bahwa belajar akan efektif melalui pembelajaran induktif dan berpusat pada pembelajar maka strategi active learning melalui Jurnal Reflektif dipilih untuk mengatasi permasalahan tersebut. Metode ini digunakan dengan berbasis pada kemampuan yang diharapkan dimiliki mahasiswa, yakni High Order Thinking Skill (HOTS) atau berpikir tingkat tinggi.

Formula yang hendak diterapkan dalam upaya tindakan dilandasi oleh adanya bukti empiris hasil penelitian yang menunjukkan bahwa formula tersebut efektif, yakni di antaranya yang telah dilakukan oleh Zazuli (2012) dalam meningkatkan motivasi belajar. Hasil penelitiannya menunjukkan bahwa kenaikan skor rata-rata dari aspek motivasi belajar matematika adalah 0,4764 atau naik sebesar $13,72 \%$. Selain itu, jurnal reflektif juga sebelumnya menjadi fokus penelitian namun dalam konteks sebagai alat evaluasi (Fauziya \& Alfa, 2015). Hasilnya menunjukkan bahwa jurnal reflektif dapat meningkatkan keterampilan menulis serta melalui jurnal reflektif juga $80 \%$ pembelajar dapat menuangkan keterpahamannya mengenai materi, mengaitkan materi dengan apa yang dialami, mengetahui hal-hal yang menjadi kendala, serta merencanakan solusi untuk mengatasi kendala yang dialami.

Selain itu, dorongan dari adanya UU Nomor 28 tahun 2014 tentang Hak Cipta menjadi salah satu regulasi yang harus diperhatikan dalam pembelajaran menulis. Dengan demikian, penting kiranya merancang metode pembelajaran yang efektif dalam proses menulis karya ilmiah untuk menghasilkan tulisan yang berkualitas dan terhindar dari unsur plagiasi.

Penulisan jurnal reflektif berbasis High Thinking Order Skill (HOTS) dalam pembelajaran menulis makalah adalah salah satu metode yang didesain berdasarkan strategi active learning yang menekankan pembelajaran berpusat pada aktivitas dan merangsang pola berpikir tingkat tinggi, sehingga menghasilkan daya kritis analitis mahasiswa. Penerapan metode ini memunculkan asumsi bahwa pembelajaran tidak hanya berfokus pada hasil, tetapi juga pada proses; serta menulis makalah tidak hanya dipandang sekadar memindahkan informasi, melainkan bagaimana mengolah informasi dan 
menuangkannya dalam bentuk tulisan yang apik. Berdasarkan asumsi tersebut, penelitian dibatasi melalui rumusan masalah 1) Apakah terdapat perbedaan kemampuan menulis makalah pada mahasiswa sebelum dan setelah menggunakan penulisan jurnal reflektif berbasis High Thinking Order Skill (HOTS)?; dan 2) Bagaimana hasil kemampuan menulis makalah pada mahasiswa?

Menulis dipandang sebagai proses penemuan (Langan, 2008: 9; dan Hedge, 2008: 302). Dari pernyataan tersebut dapat diuraikan bahwa menulis membutuhkan proses sebelumnya yang tidak bisa dilakukan begitu saja. Menulis adalah sebuah proses maka ada langkahlangkah yang harus dilalui.

Hedge (2008: 302) menguraikan bahwa proses menulis melibatkan sejumlah aktivitas, yakni menetapkan tujuan, menghasilkan gagasan, mengatur informasi, memilih bahasa yang tepat, membuat draft, membaca dan meninjau ulang, kemudian merevisi dan mengeditnya. Senadaiesia don Dotugas penyusunan makalah dengan apa yang disampaikan Hedge (2008: 16-35) mengemukakan proses menulis meliputi prapenulisan, penulisan draft pertama, perevisian, serta pengeditan, untuk selanjutnya barulisan tulisan dianggap selesai. Sekaitan dengan kompleksnya proses menulis, Langan (2008: 9) menyebutkan bahwa menulis adalah sebuah keterampilan sehingga semakin banyak seseorang berlatih menulis maka semakin baik ia menulis.

Pernyataan-pernyataan di atas merupakan landasan ihwal keterampilan menulis. Dalam hal ini, sekiranya berlaku untuk setiap jenis tulisan yang menjadi produk akhir proses tersebut.

Sementara itu, berkenaan dengan objek penelitian ini yakni makalah, makalah merupakan satu jenis karya tulis ilmiah yang membahas mengenai suatu topik tertentu. Berkenaan dengan tugas mahasiswa, Kurniawan (2015: 32) menyebutkan bahwa makalah ilmiah sering diistilahkan dengan term paper atau disingkat paper. Suyitno (2012: 27) menekankan bahwa makalah berisi informasi atau data yang bersifat faktual yang disampaikan secara objektif dan tidak memihak kepentingan-kepentingan lain. ilmiah pada mahasiswa bertujuan untuk mendorong mahasiswa mempelajari suatu tema atau kasus, meningkatkan kemampuan mahasiswa mengumpulkan data, informasi dan pengetahuan, berpikir kritis analitis, serta melatih keterampilan mahasiswa dalam menulis akademis, 
seperti apa yang diuraikan Iskandar (2009: 46). Dari tujuan tersebut, jelaslah bahwa menulis makalah sebagai karya ilmiah bukan semata memindahkan satu teks ke dalam teks lain.

Menulis makalah dalam penelitian ini dilakukan melalui penerapan penulisan jurnal reflektif. Mengapa seseorang harus melakukan refleksi dijelaskan secara detail oleh Tarrant (2013). Ia mengemukakan bahwa salah satu manfaat refleksi sangat berdampak terhadap profesionalisme. Dengan merenungkan apa yang sudah kita lakukan, kita menjadi sadar, lebih terkendali, dan lebih mampu melihat kekuatan dan kebutuhan. Selain itu, melalui refleksi, kita bisa mulai berpindah dari pemula ke ahli (Tarrant, 2103: 2).

Istilah jurnal reflektif diperoleh dari pelatihan yang dilakukan USAID PRIORITAS. Dari modul pelatihan diperoleh hakikat jurnal reflektif, yakni kumpulan catatan perenungan dan analisis tentang aktivitas serta rencana tindak lanjut untuk hal-ha yang ditemukan dalam perenungan tersebut. Dilihat dari pernyataan tersebut, jurnal reflektif bisa dikategorikan media. Namun, secara teknis, penulisannya dapat dijadikan sebagai metode pembelajaran bertujuan untuk mengevaluasi apa yang telah dilakukan, apa ketercapaiannya, apa kelemahannya, dan apa rencana selanjutnya untuk memperbaiki apa yang harus diperbaiki (USAID PRIORITAS, 2013: 157). Jurnal reflektif atau refleksi disebut oleh beberapa ahli juga sebagai jurnal belajar. Menurut Anggraeni (2009), jurnal belajar adalah dokumen yang secara terus menurus bertambah dan berkembang yang biasanya ditulis oleh pembelajar untuk mencatat kemajuan belajarnya.

Dalam Silberman (2009: 200) penulisan jurnal ini dikategorikan sebagai salah satu teknik yang diturunkan dari strategi active learning. Istilah yang digunakan adalah jurnal pembelajaran, sebuah catatan penting yang perlu disimpan peserta pembelajar.

Penulisan jurnal reflektif sebagai sebuah teknik pembelajaran ini memang memiliki aturan-aturan pembelajaran. Namun demikian, aturan ini dibuat bukan untuk mengekang atau membatasi daya pikireropembelajar, namun justru sebagai jalan dalam mengembangkan pemikiran. Hal ini seperti yang dinyatakan Rose dan Malcom (2012: 253-254) bahwa tidak banyak di antara kita dapat berpikir dengan baik tanpa mengikuti aturan sederhana. Jenis aturan-aturan yang dimaksud 
tidak membatasi, tetapi justru membebaskan kita dengan memberi kita struktur sederhana yang membimbing kita menuju hasil yang bermutu.

Jurnal reflektif yang dimaksud dalam penelitian ini dikombinasikan dengan High order thinking skill atau berpikir tingkat tinggi memiliki banyak makna dalam pembelajaran. Brookhart (2010: 3) membedakannya ke dalam tiga kategori, yakni berpikir tingkat tinggi dalam hal "transfer", "berpikir kritis" dan "pemecahan masalah".

Dalam kategori "transfer", Brookhart (2010: 3) mengutip pernyataan Anderson "Two of the most important educational goals are to promote retention and to promote transfer (which, when it occurs, indicates meaningful learning) ... retention requires that students remember what they learned, whereas transfer requires students not only to remember but also to make sense of and be able to use what they have learned." IDa pernyataan tersebut, yang dimaksud sebagai berpikir tingkat tinggi adalah pembelajar dapat mengalihkan apa yang mereka pelajari dengan cara mememahami dan menggunakannya. Artinya bahwa pembelajaran bukan semata-mata mengingat apa yang mereka pelajari.

Dalam kategori berpikir kritis, Brookhart (2010: 4) mengutip pernyataan Norris \& Ennis "Critical thinking is reasonable, reflective thinking that is focused on deciding what to believe or do." Dari pernyataan tersebut jelas bahwa berpikir tingkat tinggi maksudnya adalah berpikir secara logis atau masuk akal serta berpikir secara reflektif yang terfokus pada apa yang harus dipercayai dan dilakukan. Selain itu, Brookhart (2010: 4) juga menambahkannya dengan pernyataan Barahal bahwa berpikir kritis dipandang sebagai "artful learning", yang meliputi penalaran, pertanyaan dan penyelidikan, pengamatan dan penggambaran, perbandingan dan penghubungan, serta penemuan dan pengekslporasian sudut pandang.

\section{METODE}

Untuk menjawab rumusan masalah yang diajukan, metode penelitian yang digunakan adalah metoderh penelitian eksperimen. Penelitian ini dilaksanakan di IKIP Siliwangi. Yang menjadi subjek penelitian adalah mahasiswa Program Studi PBS. Indonesia yang menempuh mata kuliah dengan kepenulisanan dengan jumlah sampel 34 orang. 
Penelitian ini terdiri atas dua variabel, yakni jurnal reflektif berbasis HOTS sebagai variabel bebas dan kemampuan menulis makalah sebagai variabel terikat. Sesuai dengan rumusan masalah yang diajukan dan hubungan antarvariabel penelitian, model penelitian yang digunakan adalah kuantitatif. Penelitian akan dilaksanakan dengan metode eskperimen, seperti yang telah diuraikan sebelumnya.

Pengumpulan data dilakukan melalui portofolio, yakni teknik pengumpulan data yang digunakan untuk menjaring data kemampuan menulis makalah mahasiswa baik secara proses, maupun hasil. Di dalam portofolio ini akan terdiri atas makalah dan jurnal reflektif yang digunakan dalam proses pembelajaran. Dalam portofolio juga akan terdapat hasil tes awal dan tes akhir kemampuan menulis makalah baik di kelas eksperimen maupun di kelas kontrol guna menjawab rumusan masalah. Teknik analisis dilakukan secara kuantitatif. Dataid utama untuk membuktikan hipotesis yakni kemampuan menulis makalah diperoleh melalui pemberian skoring berdasarkan kriteria penilaian.

\section{HASIL DAN PEMBAHASAN}

Metode penulisan jurnal reflektif merupakan satu cara bagaimana seseorang merefleksi apa yang telah dilakukan untuk mengidentifikasi apa kelemahan dan kelebihan dalam melakukan sesuatu, dalam hal ini menulis makalah. Tujuannya adalah agar ada perbaikan untuk kegiatan selanjutnya. Cara ini diprediksi menjadi sangat penting bagi mahasiswa berhubung menulis makalah merupakan bagian dari tugas sehari-hari.

Penelitian kemampuan menulis makalah pada mahasiswa IKIP Siliwangi bersumber dari kegiatan penulisan makalah pada mahasiswa semester 2 Program Studi Pendidikan Bahasa dan Sastra Indonesia. Instrumen penilaian makalah dijadikan pedoman dalam menganalisis kemampuan menulis. Instrumen penilaian makalah tersebut meliputi tiga bagian penilaian yaitu: konvensi naskah, kebermaknaan konten dan bahasa jlmiah yang masing-masing memuat lima indikator.

Pertama, penilaian konvensi naskah meliputi: sistematika penulisan (SP), penggunaan ukuran kertas dan margin (KM), penggunaan huruf (jenis dan ukuran) (H), konsistensi sistem tipografi paragraf (P), keidealan panjang tulisan (PT). 
Kedua, penilaian kebermaknaan konten meliputi: topik signifikan bagi pembaca dan sesuai pengembangan bidang ilmu (T), paparan didukung oleh kejelasan topik melalui gaya penulisan yang mudah $(\mathrm{P})$, isi makalah yang logis dan didukung informasi dan data (IM), pengorganisasian tulisan jelas mulai dari dari Tabel 1 dapat terlihat bahwa rata-rata skor sebelum treatmen adalah 5,14 dan skor sesudah treatment adalah 6,06. Angka ini masih jauh dari hasil ideal yang diharapkan.

Tabel 1. Rata-rata Hasil Penilaian Makalah per Aspek

\begin{tabular}{|c|c|c|c|c|c|c|c|c|c|c|c|c|c|c|c|c|}
\hline \multirow[t]{2}{*}{ Kelas } & \multicolumn{5}{|c|}{ Konvensi Naskah } & \multicolumn{5}{|c|}{ Kebermaknaan Konten } & \multicolumn{5}{|c|}{ Bahasa Ilmiah } & \multirow{2}{*}{$\begin{array}{l}\text { Total } \\
\text { Skor }\end{array}$} \\
\hline & SP & KM & $\mathrm{H}$ & $\mathbf{P}$ & PT & $\mathrm{T}$ & $\mathbf{P}$ & IM & JSJ & GUGR & BB & HI & $\mathrm{KE}$ & $\mathbf{K}$ & DP & \\
\hline $\begin{array}{l}\text { Kemampuan } \\
\text { sebelum } \\
\text { treatment }\end{array}$ & 0,88 & 0,07 & 0,42 & 0,23 & 0,60 & 1,00 & 0,58 & 0,05 & 0,80 & 0,60 & 0,02 & 0,12 & 0,00 & 0,02 & 0,00 & 5,14 \\
\hline $\begin{array}{c}\text { Kemampuan } \\
\text { sesudah } \\
\text { treatment }\end{array}$ & 0,94 & 0,47 & 0,56 & 0,32 & 0,44 & 0,85 & 0,68 & 0,00 & 0,68 & 0,44 & 0,29 & 0,35 & 0,00 & 0,03 & 0,00 & 6,06 \\
\hline Gain (n) & 0,06 & 0,4 & 0,14 & 0,09 & $\overline{0,16}$ & $\begin{array}{c}- \\
0,15\end{array}$ & 0,1 & 0,05 & 0,12 & $-0,16$ & 0,27 & 0,23 & 0 & 0,01 & 0 & 0,92 \\
\hline
\end{tabular}

judul dan subjudul (JSJ), pengorganisasian tulisan jelas melalui gagasan umum dan gagasan rinci (GUGR). Ketiga, penilaian penggunaan bahasa ilmiah meliputi subaspek-subaspek berikut: bahasa baku (BB), penulisan huruf miring, huruf kapital, dan ejaan secara umum (HI), kalimat efektif (KE), penulisan kutipan (K), penulisan daftar pustaka (DP).

Berikut ini rata-rata hasil penilaian makalah sebelum dan setelah menggunakan metode Jurnal Reflektif Berbasis HOTS. Setiap indikator dalam Tabel 1 idealnya mendapat skor 1 sehingga total skor adalah idealnya adalah 15. Namun,
Dari kelima belas indikator yang dinilai, perolehan skor yang cukup bagus terlihat dari indikator Sistematika Penulisan (SP), Topik (T), dan JSJ (Pengorganisasian Judul dan Subjudul), sementara yang lainnya masih terkategori rendah.

Indikator yang paling rendah terlihat dari Isi Makalah (IM), Kálimat Efektif (KE), dan Daftar Pustaka (DP). Ketiga indikator ini mendapat skor paling rendah.

Sementara itu, dilihat dari skor selisih sebelum dan setelah treatmen, indikator Konvensi Makalah (KM), Bahasa Baku (BB), dan Huruf Miring (HI) merupakan tiga indikator yang 
cukup memiliki selisih, yakni ada peningkatan skor yang cukup tinggi dibandingkan aspek lainnya.

Contoh analisis untuk makalah adalah hasil analisis yang pertama, dalam penilaian Konvensi Naskah yaitu pada aspek (KM) penggunaan kertas dan margin, (P) sistem paragraf, dan (PT) panjang tulisan. Dalam penilaian ini rata-rata yang diperoleh adalah (KM) 0,47, (P) $(0,32)$ dan (PT) 0,44. Pada ketiga penilaian ini kesalahan penulisan yang sering terjadi. Rata-rata tersebut menjadi rata-rata tiga terbawah dalam kategori Konvensi Naskah. Pengunaan margin yang tidak tepat pada 18 makalah menandakan ketidakcermatan seorang mahasiswa dalam membuat makalah. Sistem paragraf yang tidak konsisten pada 23 makalah menjadikan kesalahan yang paling sering terjadi pada konvensi naskah. Kemudian, panjang tulisan makalah pada 19 mahasiswa masih belum memenuhi standar penulisannya. Hal ini dapat diakibatkan oleh ketidaktahuan mahasiswa maupun karena kekeliruan mahasiswa.

Kedua, terdapat pada aspek Kebermaknaan Konten dalam bagian (IM) Isi Makalah. Angka rata-rata isi makalah mahasiswa adalah 0,047. Hal ini disebabkan isi makalah dari 34 makalah yang dinilai masih jauh dari data dan informasi yang dapat dipertanggungjawabkan. Isi makalah tersebut lebih banyak mengemukakan pernyataan-pernyataan tanpa adanya informasi dan sumber yang jelas. Materi yang dipaparkan lebih banyak berdasarkan teori yang tidak dijelaskan sumber dan data yang jelas.

Ketiga, pada aspek Bahasa Ilmiah hasil penilaian yang telah dilakukan membuktikan bahwa pada aspek ini rata-rata nilai yang diperoleh sangat kecil dibandingan kedua aspek lainnya. Pada aspek Bahasa Ilmiah yang terkecil terdapat pada dua bagian yakni kalimat efektif dan daftar pustaka. Yang pertama, penilaian (KE) Kalimat efektif memperoleh nilai rata-rata 0 .

Orang berbicara menggunakan kata-kata dengan kecepatan kirakira 125 buah kata per menit dan kebanyakan orang dapat berpikir dengan mudah dengan kecepatan empat kali dari kecepatan berbicara tadi, dan ternyata hal ini amat susah sekali karena akan memperlampat okecepatan berpikir kita, sebab kita mempunyai kira-kira 400 kata per menit untuk berpikir untuk menghadapi orang yang berbicara kepada kita.

Kutipan tersebut cukup membuktikan, kalimat yang digunakan sangat tidak efektif. Hal itu karena bahasa 
yang digunakan tidak mudah dipahami, terdapat juga pengulangan kata yang dilakukan secara terusmenerus. Baik kata "dengan”, “dan”, "kita", "kira-kira", dan untuk sehingga terjadi pemborosan kata. Paragraf tersebut juga hanya terdiri atas satu kalimat saja. Hal itu juga berhubungan dengan pengungkapan gagasan umum dan gagasan rinci yang tidak tepat.

Contoh analisis lain adalah bagian Daftar Pustaka (DP). Pada penilaian ini, semua makalah tidak memenuhi syarat daftar pustaka yang baik dan benar. Rata-rata nilai pada bagian daftar pustaka ini adalah 0 . Penulisan daftar pustaka tidak mengacu pada gaya American Psychological Association (APA). Sementara di awal perkuliahan bahkan saat matrikulasi telah ditekankan bahwa gaya selingkung IKIP Siliwangi dalam menulis sebuah karya tulis ilmiah haruslah menggunakan gaya APA. Ketidaksesuaian ini terjadi dalam beberapa hal, meliputi nama penulis yang tidak ditulis dari nama belakang, bahkan nama penulis yang ditulis lengkap dengan gelar, judul yang tidak dicetak miring, dan yang paling banyak keliru adalah pada penulisan daftar pustaka dari online yang hanya mencantumkan alamat URL-nya saja.

Sebagai bahan pembuktian hipotesis, berikut ini rekapitulasi nilai dari konversi skor yang telah diperoleh. 
Untuk membuktikan hipotesis mengenai keefektifan metode Jurnal Reflektif dalam menulis makalah, Tabel 2 adalah output hasil pengujian paired sample t-test dengan menggunakan aplikasi SPSS.
Berikut ini asumsi berdasarkan jurnal reflektif hasil penulisan mahasiswa.

Pertama, tujuan menulis makalah bagi mahasiswa $85 \%$ adalah untuk memenuhi tugas. Kedua, $85 \%$ mahasiswa mengaku tidak puas

\section{Tabel 2}

Pengujian Perbedaan Nilai Kemampuan Menulis Sebelum dan Setelah Penggunaan Metode Jurnal Reflektif dengan Paired Sampel Test

Paired Samples Test

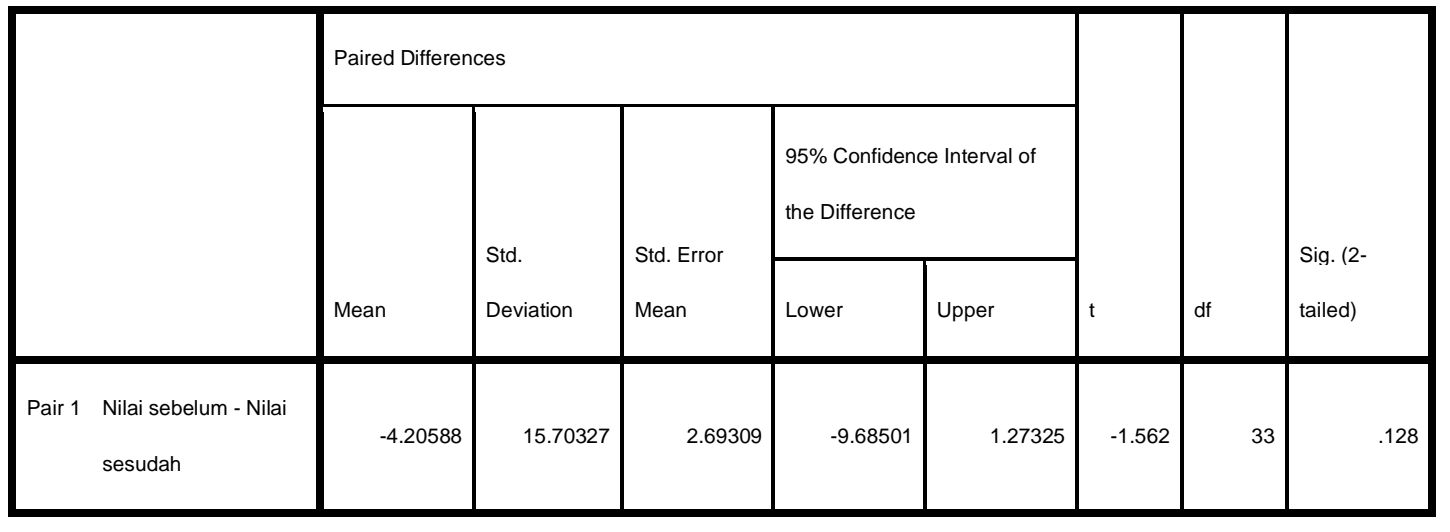

Berdasarkan Tabel 2, diperoleh nilai signifikansi 0,128 dengan $\mathrm{a}=$ 0,05 . Signifikansi $0,128>0,05$ menunjukkan bahwa tidak terdapat perbedaan antara nilai kemampuan menulis makalah sebelum dan setelah perlakuan. Hal ini memberikan kesimpulan bahwa penulisan jurnal reflektif dalam bentuk matriks reflektif tidak memberikan pengaruh terhadap keterampilan mahasiswa dalam menulis makalah. Pengujian ini ditengarai oleh beberapa faktor. dalam menulis makalah (tidak untuk tujuan pemenuhan kepuasan intelektual). Ketiga, $90 \%$ penulisan makalah didasarkan pada pemindahan pernyataan dari sumber baik dari buku referensi maupun dari internet (copy-paste). Keempat, $\quad 80 \%$ mahasiswa mengakui mengalami kesulitan dalam menulis makalah, tetapi tidak berupaya mencari solusinya dan selalu melakukan hal yang sama. Kesulitan yang dimaksud adalah menuangkan ide dengan 
bahasa sendiri dan menghindari plagiasi. Kelima, $60 \%$ mengaku kurang ada bimbingan dari dosen tentang menulis makalah.

Data pendukung hasil menulis jurnal reflektif menunjukkan akar permasalahan menulis makalah terjadi pada tujuan utama dalam menulis makalah itu sendiri. Menulis makalah sebagai satu bagian dari sekadar "menggugurkan kewajiban" adalah sumber utama ketidakberhasilan dalam menulis. Salah satu manfaat menulis makalah adalah kepuasan intelektual. Inilah yang seharusnya menjadi dasar dalam proses menulis. Selain itu, kesadaran mahasiswa berdasarkan refleksi tidak cukup membuat ia melakukan hal yang lebih baik. Ini menjadi satu hasil yang membuktikan bahwa perlu ada perlakuan lebih konkret untuk dapat membuat seseorang berubah.

Data pendukung lainnya adalah tes praktik mengenai pengetahuan mahasiswa dalam menulis makalah. Hasilnya adalah pertama, mahasiswa mengetahui konvemsi sistematik penulisan, layout (kertas dan margin), penggunaan huruf, sistem paragraf, serta panjang tulisan. Hal ini karena konvensi naskah telah disepakati di awal. Kedua, mahasiswa mengetahui ihwal kebermaknaan konten. Artinya mereka tahu bahwa isi makalah akan dipertanggungjawabkan untuk dipresentasikan, permasalahannya adalah presentasi yang mereka maknai tidak untuk dipahami di luar kepala. Ketiga adalah mereka mengetahui penggunaan Bahasa dalam karya ilmiah, baik dari Bahasa baku, konsistensi penggunaan huruf, kalimat, kutipan dan daftar pustaka. Simpulannya, secara pengetahuan mereka telah memadai namun pengetahuan tersebut tidak digunakan untuk menunjang praktik keterampilan.

\section{SIMPULAN}

Berdasarkan paparan hasil dan pembahasan diperoleh simpulan bahwa Pertama, tidak terdapat perbedaan antara kemampuan menulis makalah sebelum dan setelah penerapan metode penulisan jurnal reflektif, dibuktikan dengan nilai signifikansi $0,128>0,05$. Hal ini membuktikan bahwa mampu merefleksi diri dan merencanakan perbaikan tidak cukup membuat kemampuan praktik/keterampilan menjadi lebih baik. Kedua, nilai menulishmakalah mahasiswa masih berada pada rata-rata nilai 40. Ini menunjukkan bahwa kemampuan menulis mahasiswa masih jauh di bawah nilai ideal yang diharapkan, yakni minimal 80. dari hasil menulis makalah diperoleh aspek-aspek kelemahan, yakni 1) Aspek konvesi 
makalah yang berkaitan dengan ketepatan ukuran kertas dan margin, serta konsistensi tipografi paragraf; 2) Aspek kebermaknaan konten yang berkaitan dengan isi makalah karena tidak memaparkan informasi sesuai data yang jelas; 3) Aspek bahasa ilmiah berkait dengan kalimat efektif, penulisan kutipan dan daftar pustaka. Hasil analisis tersebut dapat dipengaruhi oleh faktor penyebab. 1) kesalahan penulisan diakibatkan oleh kurang cermatnya mahasiswa dalam menulis makalah dan tidak memerhatikan pedoman penulisan; 2) mahasiswa mengetahui pedoman dan kaidah penulisan makalah namun kurang tepat pada pengimplementasiannya. Untuk pembelajaran dan penelitian selanjutnya, diperlukan penerapan metode yang lebih konkret dan aplikatis agar mampu meningkatkan keterampilan menulis makalah bagi mahasiswa.

\section{DAFTAR PUSTAKA}

Anggraeni, S. 2009. Pengaruh Penggunaan Jurnal Belajar (Learing Journal) terhadap Hasil

Belajar Siswa pada Konsep Sistem Reproduksi Manusia.

Skripsi. Bandung: FPMIPA Universitas Pendidikan Indonesia.

Brookhart, S.M. 2010. How to Assess Higher-Order Thinking Skills in Your Classroom. Alexandria: ASCD.
Cahyani, I. 2010. Peningkatan Kemampuan Menulis Makalah melalui Model Pembelajaran Berbasis Penelitian pada Mata Kuliah Umum Bahasa Indonesia. Jurnal Sosiohumanika Vol. 3 No. 2, Hlm. 175-192.

Fauziya, D.S. \& Alfa M.S. 2015. Evaluasi Pembelajaran melalui Penulisan Jurnal Reflektif Berbasis Penilaian Diri di PBS. Indonesia STKIP Siliwangi Bandung. Jurnal Ilmiah UPT P2M STKIP Siliwangi. Vol. 2. No. 1. Hlm. 46-52.

Hedge, T. 2008. Teaching and Learning in the Language Classroom. New York: Oxford University Press.

Iskandar, M. 2009. Penentuan Ciriciri Plagiarisme dalam Makalah Ilmiah yang Mereferensi Sumber dalam Bahasa Asing yang Diterjemahkan. Bina Ekonomi Majalah Ilmiah Fakultas Ekonomi Unpar Vol. 13 No. 1 Hilm. 46-12.

Kurniawan, K. 2015. Bahasa Indonesia Keilmuan untuk Perguruan Tinggi. Bandung: Refika Aditama. 
Langan, J. 2008. Exploring Writing: Paragraphs and Essays. New York: McGraw-Hill.

Rose, C. \& Malcom J.N. 2012. Accelerated Learning for the $21^{\text {st }}$ Century. Diterjemahkan oleh Dedy Ahimsa. Bandung: Nuansa.

Sanjaya, W. 2009. Penelitian Tindakan Kelas. Jakarta: Kencana Prenada Media.

Surat Dirjen Dikti No. 152/E/T/2012 tentang Publikasi Karya Ilmiah.

Suyitno. 2012. Menulis Makalah dan Artikel. Bandung: Refika Aditama.

Tarrant, Petter. 2013. Reflective Practice and Professional Development. London: Sage Publications.

USAID PRIORITAS. 2013. Praktik yang Baik dalam Pembelajaran. Jakarta: tidak diterbitkan.
UU Nomor 28 tahun 2014 tentang Hak Cipta.

Yuwono, A. 2009. Optimalisasi Web

Internet sebagai Usaha

Peningkatan Kemampuan

Menulis Karya Ilmiah

Mahasiswa Prodi PBSJ Semester

VIII FBS Unnes. Dalam Jurnal

Lingua V/I Januari 2009 Hlm. 73-

83.

Warsono. 2012. Pancasilaisme dalam

Dinamika Pendidikan. Surabaya:

Unesa University Press.

Zazuli, I. 2012. Penggunaan Buku Jurnal Reflektif (BJR) untuk Meningkatkan Motivasi Belajar Matematika di SMP Negeri 3 Ngaglik Sleman. Tesis pada Universitas Gadjah Mada. Yogyakarta: Tidak diterbitkan 